\title{
EFFECTS OF UREA AND POULTRY MANURE COMBINATION ON YIELD AND QUALITY OF DIFFERENT LETTUCE (Lactucasativa L.) VARIETIES IN CHITWAN, NEPAL
}

\author{
S. Ghimire ${ }^{1^{*}}$, A. Nainabasti ${ }^{2}$, M.D. Sharma ${ }^{3}$, S. Marahatta ${ }^{3}$, H.N. Giri ${ }^{3}$ \\ ${ }^{1}$ Ministry of Land Management, Agriculture and Cooperative, Province-5, Rupandehi \\ ${ }^{2}$ Ministry of Agriculture and Livestock Development, Singhadurbar, Kathmandu \\ ${ }^{3}$ Agriculture and Forestry University, Rampur, Chitwan
}

\begin{abstract}
A study was conducted to evaluate the effect of combined application of urea and poultry manure(viz., $100 \% \mathrm{~N}$-urea, $75 \% \mathrm{~N}$-urea $+25 \% \mathrm{~N}-\mathrm{PM}$, $50 \% \mathrm{~N}$-urea $+50 \% \mathrm{~N}-\mathrm{PM}, 25 \% \mathrm{~N}$-urea $+75 \% \mathrm{~N}-\mathrm{PM}$ and $100 \% \mathrm{~N}-\mathrm{PM}$ ) on yield and quality of two varieties of lettuce viz., Green Span and NAI RE KUI DA F1at the Horticulture Farm of Agriculture and Forestry University, Rampur, Chitwan, Nepal from October 30, 2015 to January 30,2016 . Results revealed that the integration of $50 \%$ or more N-PM had significantly higher values in growth, yield and quality parameters while the use of $100 \% \mathrm{~N}$-urea had the lowest one. Similarly, the two varieties significantly differed in all characters and the variety Green Span performed better at all levels of integration of $\mathrm{N}$-urea with $\mathrm{N}$-poultry manure than NAI RE KUI DA F1. Based on interaction effect, Green Span performed better with $100 \%$ N-poultry manure while NAI RE KUI DA F1 did better with the combination of $50 \% \mathrm{~N}$-urea and $50 \% \mathrm{~N}-\mathrm{PM}$.
\end{abstract}

\section{INTRODUCTION}

Lettuce (Lactuca sativa) is globally important cool season leafy vegetables. It is taken as synonym of "salads" and contains about 6-19\% mineral elements on the dry weight basis. It is the richest source of calcium among other vegetables and is the second richest source of minerals after spinach. The milky liquid substance, latex, present in lettuce contains "Lactucin" and 'Lactucopicrin' which helps to regulate nervous system, improves sleepiness, appetite and digestion and reduces high blood pressure, lowers high cholesterol levels, lowers inflammation and provides a supply of antioxidants (Sharma, 2005).It is minor crop in case of Nepal and its cultivation and consumption is mainly confined to Kathmandu and Pokhara valley where tourism industry has been flourished. However, with the growing increment in living standard of people, increasing awareness among people about health benefits of

*Corresponding author email : susmaghimiray@gmail.com 
lettuce and also with the improvement of tourism in Nepal, its market demand has been increasing. Limited research and extension work has been conducted on it.

Lettuceis short duration high value crop with higher productivity which can be obtained through optimum nutrient use provided through organic, inorganic or biofertilizer sources. Chemical fertilizers are expensive and along with increment in production results in poor health condition of soil and water when used repeatedly. Public concern has been increased about the health and environmental hazardous brought by excessive use of inorganic fertilizers. Use of higher dose of inorganic source of nitrogen as urea in leafy vegetables has come up with the problem of accumulation of nitrate which is highly toxic substance to human being. Organic manure is arising as alternative practice to inorganic fertilizer and its use reduces the amount of nitrates together with increase in quality and yield of lettuce (Naeem, Iqbal and Bakhsh, 2006). However, for the use of organic manure, no clear recommendation is available. Farmers tend to apply either too much or too low organic fertilizers due to which soil condition is influenced and amount of nutrients provided by them is either insufficient or over dose for plants (Mbatha, 2008). Precise calculation of rate of use of organic manure is very important as their nutrient sources; composition as well as mineralization rate differs. Also, it is essential to improve and maintain soil fertility for higher productivity of vegetable crops, for which the advantages and disadvantages of organic and inorganic fertilizers need to be integrated in order to make optimum use of each type and achieve balanced nutrient management for crop growth (Chen, 2006). This research study is aimed at generating information on the optimum sole organic manure, inorganic fertilizer or combinations for optimum yields and quality along with appropriate varietal selection of lettuce that can be utilized by those interested in commercializing it.

\section{MATERIALS AND METHODS}

The experiment was carried out at the Vegetable Farm of Agriculture and Forestry University, Rampur, Chitwan from the month of October, 30, 2015 to January 30, 2016. It is situated at $27^{\circ} 40^{\prime}$ North latitude and $84^{\circ} 19^{\prime}$ East longitude with elevation of 228 masl. The location is inner Terai with humid sub-tropical climate. The average temperature during the field research was $20.4^{\circ} \mathrm{C}$. The experimental site had acidic soil with $\mathrm{pH} 5.5$, soil texture was sandy loam with $1.4 \%$ organic matter, low nitrogen level $(0.08 \%)$, high phosphorous $\left(360 \mathrm{~kg} \mathrm{ha}^{-1}\right)$ and medium potash $\left(146 \mathrm{~kg} \mathrm{ha}^{-1}\right)$. Similarly, poultry manure analysis data showed that $\mathrm{N}, \mathrm{P}_{2} \mathrm{O}_{5}$, and $\mathrm{K}_{2} \mathrm{O}$ content were $1.06 \%, 0.79 \%$ and $0.52 \%$ respectively. The two factor experiment was laid out in RCBD, where nutrient management with combined use of nitrogen from urea $(\mathrm{N}-$ urea) and poultry manure (N-PM) was one factor and variety was the next. Green Span is a released open pollinated variety of leafy type while NAI RE KUI DA F1 is a hybrid romaine leaf type variety. 
There were altogether 10 treatment combinations and 4 replications. Total experimental area was $218.5 \mathrm{~m}^{2}(23 \mathrm{~m} \times 9.5 \mathrm{~m})$. Space between replication or main plot was $1 \mathrm{~m}$ and space between sub-plots was $0.5 \mathrm{~m}$. The individual plot size was 3.375 $\mathrm{m}^{2}(2.25 \mathrm{~m} \times 1.5 \mathrm{~m})$. The row to row distance was $45 \mathrm{~cm}$ and plant to plant distance was $30 \mathrm{~cm}$ apart. There were 5 rows of in each plot and 5 plants comprised a single row thus compromising 25 plants in each plot. Out of five rows, 2 rows were taken as boarder plants and remaining 3 rows were used for observation. Five randomly selected plants from these three rows were taken for observation.

Nursery was prepared at $3^{\text {rd }}$ October and transplanted in main field 30 days after sowing. While fertilizing the land, total amount of urea and poultry manure applied depended on respective nutrient combination. Poultry manure was applied at double dose of calculated amount and half dose of nitrogen, full dose of phosphorus and potassium was applied after calculating the required amount as per nutrient combination with references to the recommended dose of 120:60:40@NPK kg ha ${ }^{-1}$. Remaining a lf dose of nitrogen $\left(25 \mathrm{~kg} \mathrm{ha}^{-1}\right)$ was applied at 25 DAT.

Data regarding the growth parameters like leaf length and breadth of leaves, number of leaves per plant, economic yield and quality parameters as vitamin $\mathrm{C}$ were taken and analyzed using RSTAT and Microsoft excel and interpretations were made based on results and findings. The purpose of analysis of variance was to determine the significant effect of nutrient combination and varieties on yield and quality of lettuce.

\section{RESULTS AND DISCUSSION}

\section{Effect of varieties and different combination of $\mathrm{N}$-urea and $\mathrm{N}$-poultry manure}

The data in table show the statistically significant variation for all the growth parameters, yield and quality of lettuce at the time of harvest. The highest records of number of leaves $(21.11)$, leaf length $(17.75 \mathrm{~cm})$, plant height $(19.41 \mathrm{~cm})$,economic yield $\left(15.05 \mathrm{t} \mathrm{ha}^{-1}\right)$ was found in the nutrient combination of $50 \% \mathrm{~N}$-urea $+50 \% \mathrm{~N}$ PM and above ground mass $\left(20.16 \mathrm{t} \mathrm{ha}^{-1}\right)$, leaf breadth $(18.32 \mathrm{~cm})$, rosette diameter $(32.05 \mathrm{~cm})$, dry weight $(14.17 \%)$ and Vitamin C $\left(16.50 \mathrm{mg} 100 \mathrm{~g}^{-1}\right)$ was found highest in $100 \% \mathrm{~N}$-poultry manure. However, it was found that the nutrient combination of $50 \% \mathrm{~N}$-urea $+50 \% \mathrm{~N}-\mathrm{PM}, 25 \% \mathrm{~N}$-urea $+75 \% \mathrm{~N}-\mathrm{PM}$ and $100 \% \mathrm{~N}-\mathrm{PM}$ were statistically at par for all growth parameters. The lowest record in all the parameters was observed in $100 \% \mathrm{~N}$-urea followed by $75 \% \mathrm{~N}$-urea $+25 \%$ poultry manure. Among the two varieties, NAI RE KUIDA F1 and Green Span, all growth parameters, above ground mass and economic yield was found significantly higher in Green Span than NAI RE KUI DA F1 but in Vitamin C, no significant difference was found between two varieties. 
Table 1. Effect of varieties and different combination of $\mathrm{N}$-urea and N-poultry manure on number of leaves, leaf length, leaf breadth, economic yield and Vitamin C of lettuce at Rampur, Chitwan, Nepal (2015/16)

\begin{tabular}{|c|c|c|c|c|c|}
\hline Treatments & $\begin{array}{c}\text { Plant } \\
\text { height }(\mathrm{cm})\end{array}$ & $\begin{array}{l}\text { No. of } \\
\text { Leaves }\end{array}$ & $\begin{array}{l}\text { Leaf } \\
\text { Length } \\
(\mathrm{cm})\end{array}$ & $\begin{array}{c}\text { Leaf } \\
\text { Breadth } \\
(\mathrm{cm})\end{array}$ & $\begin{array}{l}\text { Rosette } \\
\text { diameter } \\
(\mathrm{cm})\end{array}$ \\
\hline \multicolumn{6}{|c|}{ Combination of N-urea with N-poultry manure } \\
\hline $100 \%$ N-urea & $14.35^{\mathrm{b}}$ & $17.25^{\mathrm{b}}$ & $13.39^{\mathrm{b}}$ & $14.18^{\mathrm{c}}$ & $24.44^{\mathrm{b}}$ \\
\hline $75 \%$ N-urea $+25 \%$ N-PM & $15.25^{\mathrm{b}}$ & $18.58^{\mathrm{b}}$ & $14.70^{\mathrm{b}}$ & $16.05^{\mathrm{bc}}$ & $26.63^{\mathrm{b}}$ \\
\hline $50 \% \mathrm{~N}$-urea $+50 \% \mathrm{~N}-\mathrm{PM}$ & $19.41^{\mathrm{a}}$ & $22.11^{\mathrm{a}}$ & $17.75^{\mathrm{a}}$ & $17.48^{\mathrm{ab}}$ & $31.4^{\mathrm{a}}$ \\
\hline $25 \%$ N-urea $+75 \%$ N-PM & $18.95^{\mathrm{a}}$ & $21.26^{\mathrm{a}}$ & $16.89^{\mathrm{a}}$ & $17.15^{\mathrm{ab}}$ & $30.84^{\mathrm{a}}$ \\
\hline $100 \%$ N-PM & $19.28^{\mathrm{a}}$ & $23.33^{\mathrm{a}}$ & $17.52^{\mathrm{a}}$ & $18.32^{\mathrm{a}}$ & $32.05^{\mathrm{a}}$ \\
\hline $\operatorname{SEM}( \pm)$ & 3.56 & 4.58 & 2.16 & 2.49 & 7.71 \\
\hline $\operatorname{LSD}_{(0.05)}$ & 2.24 & 2.54 & 1.74 & 1.87 & 2.08 \\
\hline$P$ value & 0.000 & 0.000 & 0.000 & 0.001 & 0.000 \\
\hline \multicolumn{6}{|l|}{ Varieties } \\
\hline NAI RE KUI DA F1 & $15.296^{\mathrm{b}}$ & $19.02^{\mathrm{b}}$ & $13.94^{\mathrm{b}}$ & $14.34^{\mathrm{b}}$ & $25.81^{\mathrm{b}}$ \\
\hline Green Span & $19.608^{\mathrm{a}}$ & $21.98^{\mathrm{a}}$ & $18.16^{\mathrm{a}}$ & $18.93^{\mathrm{a}}$ & $32.33^{\mathrm{a}}$ \\
\hline $\operatorname{SEM}( \pm)$ & 3.56 & 4.58 & 2.16 & 2.49 & 7.71 \\
\hline $\operatorname{LSD}_{(0.05)}$ & 1.41 & 1.61 & 1.10 & 1.18 & 2.08 \\
\hline $\mathrm{P}$ value & 0.000 & 0.000 & 0.000 & 0.000 & 0.000 \\
\hline Mean & 17.45 & 20.50 & 16.05 & 16.63 & 29.07 \\
\hline CV (\%) & 10.81 & 10.44 & 9.15 & 9.49 & 9.55 \\
\hline
\end{tabular}

Means within the column followed by same letter are not significant at $5 \%$ level by DMRT. DAT=Days after transplanting, SEM $( \pm)=$ Standard error of mean, LSD=least significant difference and $\mathrm{CV}=$ coefficient of variance 
Table 2. Effect of varieties and different combination of N-urea and N-poultry manure on above ground mass, economic yield, dry weight and Vitamin C of lettuce at Rampur, Chitwan, Nepal (2015/16)

\begin{tabular}{|c|c|c|c|c|}
\hline Treatments & $\begin{array}{l}\text { Above } \\
\text { ground mass } \\
\left(\text { tha }^{-1}\right)\end{array}$ & $\begin{array}{c}\text { Economic } \\
\text { Yield }\left(\text { tha }^{-1}\right)\end{array}$ & $\begin{array}{c}\text { Dry } \\
\text { weight }(\%)\end{array}$ & $\begin{array}{r}\text { Vitamin C } \\
\left(m g 100 g^{-1}\right)\end{array}$ \\
\hline \multicolumn{5}{|c|}{ Combination of $\mathrm{N}$-urea with $\mathrm{N}$-poultry manure } \\
\hline $100 \% \mathrm{~N}$-urea & $17.67^{\mathrm{c}}$ & $12.67^{\mathrm{b}}$ & $7.67^{\mathrm{b}}$ & $13.17^{\mathrm{b}}$ \\
\hline $75 \%$ N-urea $+25 \%$ N-PM & $18.79^{\mathrm{b}}$ & $14.3^{\mathrm{a}}$ & $9.33^{\mathrm{b}}$ & $14.23^{\mathrm{b}}$ \\
\hline $50 \%$ N-urea $+50 \%$ N-PM & $19.37^{\mathrm{ab}}$ & $15.05^{\mathrm{a}}$ & $13.50^{\mathrm{a}}$ & $16.40^{\mathrm{a}}$ \\
\hline $25 \%$ N-urea $+75 \%$ N-PM & $19.02^{\mathrm{b}}$ & $14.96^{\mathrm{a}}$ & $12.67^{\mathrm{a}}$ & $16.41^{\mathrm{a}}$ \\
\hline $100 \% \mathrm{~N}-\mathrm{PM}$ & $20.16^{\mathrm{a}}$ & $14.97^{\mathrm{a}}$ & $14.17^{\mathrm{a}}$ & $16.50^{\mathrm{a}}$ \\
\hline $\operatorname{SEM}( \pm)$ & 0.44 & 0.58 & 1.11 & 0.922 \\
\hline $\operatorname{LSD}_{(0.05)}$ & 0.79 & 0.91 & 2.33 & 1.142 \\
\hline$P$ value & 0.000 & 0.000 & 0.000 & 0.000 \\
\hline \multicolumn{5}{|l|}{ Varieties } \\
\hline NAI RE KUI DA F1 & $17.57^{\mathrm{b}}$ & $13.4^{\mathrm{b}}$ & $10.20^{\mathrm{b}}$ & 15.41 \\
\hline Green Span & $20.44^{\mathrm{a}}$ & $15.29^{\mathrm{a}}$ & $12.73^{\mathrm{a}}$ & 15.27 \\
\hline $\operatorname{SEM}( \pm)$ & 0.44 & 0.58 & 0.702 & 0.92 \\
\hline $\operatorname{LSD}_{(0.05)}$ & 0.5 & 0.57 & 1.48 & NS \\
\hline $\mathrm{P}$ value & 0.000 & 0.000 & 0.001 & \\
\hline Mean & 18.76 & 14.39 & 11.47 & 15.34 \\
\hline $\mathrm{CV}(\%)$ & 15.08 & 5.32 & 16.75 & 6.25 \\
\hline
\end{tabular}

Means within the column followed by same letter are not significant at $5 \%$ level by DMRT. DAT=Days after transplanting, SEM $( \pm)=$ Standard error of mean, LSD=least significant difference and $\mathrm{CV}=$ coefficient of variance.

The reason behind significant effect of the varieties on growth, yield and quality parameters might be the highly heritable characters of plant receiving the equivalent dose of fertilizer. The integration of $50 \%$ or more nitrogen through poultry manure with urea had significant effect on measured parameters which might be due to synergetic effect of both the sources or the nutrient efficiency of combining urea and poultry manure. The positive influence of poultry manure on the growth and yield of lettuce crop might be due to the release of the balanced nutrients contained in the organic nutrient especially nitrogen which ensures favorable condition for the elongation of lettuce plant as well as availability of other macro and trace elements and improvement in soil physical structure as water holding capacity. Similar result was obtained by Madisa, Mathowa, Mpofu, Stephen, and Machacha (2013) in Corchorus olitorius and $\mathrm{Xu}$ et al. (2005) in a study on leafy vegetables. The leaf proliferation and expansion in leaf vegetables attributed to organic soil amendments, 
had been demonstrated in field experiments by Sanchez and Miller, (1986); Obatolu, (1995) and Richert and Salomon, (1998). Also the urea when used in combination act as catalyst for decomposition of poultry manure and helps in the release of nutrients essential for crop during whole crop period. Dutta, Chakeraborty, and Chakrabarti (2003) reported that the use of organic fertilizers together with chemical fertilizers, compared to the addition of organic fertilizers alone, had a higher positive effect on microbial biomass and hence soil health. Ullah, Islam, Islam and Haque (2008) reported that application of organic and inorganic fertilizers solely or combined had a great influence on the vegetative growth of the crop. Similarly, the higher ascorbic acid grown organically compared to those grown conventionally was found by Schuphan (1974). But Lairon, Spitz, Termine, Ribaud, Lafont and Hauton (1984) observed no difference in vitamin $\mathrm{C}$ content of lettuce grown organically and conventionally. This study also established that the sole use of $\mathrm{N}$-urea is found inferior to rest of the treatment. The reason behind this might be that inorganic fertilizer do not possess good characteristics in aggregating soil particles and have low ability of moisture retention as reported by Masarirambi et al. (2012). Okokoh and Bisong (2011) also reported that applying N-urea without organic manure produced scanty foliage whereas poultry manure alone had superior effect over any rate of $\mathrm{N}$-urea-N on development of foliage.

\section{Interaction effect of varieties and different combination of $\mathrm{N}$-urea and $\mathrm{N}$ - poultry manure}

Interaction effect of different nutrient combinations and varieties showed statistically significant variation in leaf length, above ground mass and dry weight of lettuce.

The leaf length and dry weight of both varieties was statistically at par only at $50 \%$ $\mathrm{N}$-urea $+50 \% \mathrm{~N}-\mathrm{PM}$ nutrient combination and they differ in other. The highest leaf length and dry weight of Green Span was found with $100 \%$ N-PM $(21.43 \mathrm{~cm}$ and $16 \%$ respectively) which was statistically at par with the nutrient combination of $25 \%$ $\mathrm{N}$-urea $+75 \% \mathrm{~N}-\mathrm{PM}$ and $50 \% \mathrm{~N}$-urea $+50 \% \mathrm{~N}-\mathrm{PM}$ while the lowest was found with $100 \% \mathrm{~N}$-urea $(15.54 \mathrm{~cm}$ and $8.67 \%$ respectively) which was statistically at par with $75 \% \mathrm{~N}$-urea $+25 \% \mathrm{~N}-\mathrm{PM}$. The highest above ground mass was found in Green Span with $100 \%$ N-PM $\left(22.5 \mathrm{t} \mathrm{ha}^{-1}\right)$ while the lowest was found with $100 \%$ Urea $(18.91 \mathrm{t}$ $\mathrm{ha}^{-1}$ ) while other nutrient combination had intermediate effect on it. Similarly, NAI RE KUI DA F1 had longest leaf length, highest above ground mass and dry weight with $50 \% \mathrm{~N}$-urea $+50 \% \mathrm{~N}-\mathrm{PM}\left(16.70 \mathrm{~cm}, 18.55 \mathrm{t} \mathrm{ha}^{-1}\right.$ and $14.33 \%$ respectively $)$ which followed by with $25 \% \mathrm{~N}$-urea $+75 \% \mathrm{~N}-\mathrm{PM}$ and the lowest was found with $100 \% \mathrm{~N}$-urea which was statistically similar with $75 \% \mathrm{~N}$-urea $+25 \% \mathrm{~N}-\mathrm{PM}$ and $100 \%$ N-PM. 
Table 3. Effect of varieties and different combination of N-urea and N-poultry manure on number of leaves, rosette diameter, above ground and economic yield, and Vitamin C of lettuce at Rampur, Chitwan, Nepal (2015/16)

\begin{tabular}{|c|c|c|c|c|c|}
\hline Treatments & $\begin{array}{l}\text { No. of } \\
\text { leaves }\end{array}$ & $\begin{array}{c}\text { Rosette } \\
\text { diameter } \\
(\mathrm{cm})\end{array}$ & $\begin{array}{l}\text { Above } \\
\text { ground } \\
\text { yield } \\
\left(\text { tha }^{-1}\right)\end{array}$ & $\begin{array}{c}\text { Economic } \\
\text { yield } \\
\left(\text { tha }^{-1}\right)\end{array}$ & $\begin{array}{l}\text { Vitamin 'C' } \\
\left(\operatorname{mg} 100 g^{-1}\right)\end{array}$ \\
\hline NAI RE KUI DA F1 X $100 \%$ U & 15.26 & 21.13 & 16.44 & 11.18 & 13.61 \\
\hline Green Span X $100 \%$ U & 19.23 & 27.76 & 18.91 & 14.16 & 12.7 \\
\hline $\begin{array}{l}\text { NAI RE KUI DA F1 X ( } 75 \% \text { U } \\
+25 \% \text { PM })\end{array}$ & 17.36 & 22.75 & 17.42 & 13.67 & 14.10 \\
\hline $\begin{array}{l}\text { Green Span X ( } 75 \% \mathrm{U}+25 \% \\
\text { PM ) }\end{array}$ & 19.80 & 30.51 & 20.17 & 14.93 & 14.36 \\
\hline $\begin{array}{l}\text { NAI RE KUI DA F1 X ( } 50 \% \text { U } \\
+50 \% \text { PM })\end{array}$ & 22.63 & 30.13 & 18.55 & 14.55 & 16.86 \\
\hline $\begin{array}{l}\text { Green Span X ( } 50 \% \mathrm{U}+50 \% \\
\text { PM ) }\end{array}$ & 21.60 & 32.66 & 20.20 & 15.55 & 16.14 \\
\hline $\begin{array}{l}\text { NAI RE KUI DA F1 X ( } 25 \% \text { U } \\
+75 \% \text { PM ) }\end{array}$ & $20.0^{\mathrm{b}}$ & 28.46 & 17.37 & 14.15 & 16.46 \\
\hline $\begin{array}{l}\text { Green Span X ( } 25 \% \mathrm{U}+75 \% \\
\text { PM ) }\end{array}$ & 22.53 & 33.21 & 20.68 & 15.76 & 16.36 \\
\hline $\begin{array}{l}\text { NAI RE KUI DA F1 X ( } 100 \% \\
\text { PM ) }\end{array}$ & 19 & 26.61 & 18.08 & 13.9 & 16 \\
\hline Green Span X ( 100 \% PM ) & 26.73 & 37.50 & 22.25 & 16.03 & 16.76 \\
\hline Mean & 20.5 & 29.07 & 19.01 & 14.39 & 15.34 \\
\hline $\operatorname{SEM}( \pm)$ & 4.58 & 7.71 & 0.44 & 0.58 & 0.92 \\
\hline $\operatorname{LSD}_{(0.05)}$ & NS & NS & NS & NS & NS \\
\hline $\mathrm{CV}(\%)$ & 10.44 & 9.55 & 3.51 & 5.32 & 6.25 \\
\hline
\end{tabular}

Means within the column followed by same letter are not significant at $5 \%$ level by DMRT. DAT=Days after transplanting, SEM $( \pm)=$ Standard error of mean, LSD=least significant difference and $\mathrm{CV}=$ coefficient of variance 
Table 4. Interaction effect of varieties and different combination of N-urea and Npoultry manure on leaf length of lettuce at Rampur, Chitwan, Nepal $(2015 / 16)$

\begin{tabular}{|c|c|c|c|c|c|c|}
\hline \multirow{3}{*}{$\begin{array}{l}\text { Nutrient } \\
\text { combinations }\end{array}$} & \multicolumn{6}{|c|}{ Varieties } \\
\hline & \multicolumn{2}{|c|}{$\begin{array}{l}\text { Leaf length } \\
(\mathrm{cm})\end{array}$} & \multicolumn{2}{|c|}{$\begin{array}{l}\text { Above ground mass } \\
\qquad\left(\text { tha }^{-1}\right)\end{array}$} & \multicolumn{2}{|c|}{$\begin{array}{c}\text { Dry weight } \\
\left(\text { tha }^{-1}\right)\end{array}$} \\
\hline & Green Span & $\begin{array}{l}\text { NAI RE } \\
\text { KUI DA } \\
\quad \text { F1 }\end{array}$ & $\begin{array}{l}\text { Green } \\
\text { Span }\end{array}$ & $\begin{array}{c}\text { NAI } \\
\text { RE } \\
\text { KUI } \\
\text { DA F1 }\end{array}$ & $\begin{array}{l}\text { Green } \\
\text { Span }\end{array}$ & $\begin{array}{l}\text { NAI RE } \\
\text { KUI DA F1 }\end{array}$ \\
\hline $100 \%$ N-urea & $15.54^{\mathrm{de}}$ & $11.24^{\mathrm{f}}$ & $18.91^{\mathrm{c}}$ & $16.44^{\mathrm{e}}$ & $8.67^{\mathrm{ef}}$ & $6.67^{\mathrm{f}}$ \\
\hline $\begin{array}{l}75 \% \text { N-urea }+25 \% \\
\text { N-PM }\end{array}$ & $15.74^{\text {de }}$ & $13.67^{\mathrm{f}}$ & $20.17^{\mathrm{b}}$ & $17.42^{\mathrm{de}}$ & $10.67^{\mathrm{de}}$ & $8.00^{\mathrm{ef}}$ \\
\hline $\begin{array}{l}50 \% \text { N-urea }+50 \% \\
\text { N-PM }\end{array}$ & $18.81^{b c}$ & $16.70^{\mathrm{cd}}$ & $20.20^{\mathrm{b}}$ & $18.55^{\mathrm{c}}$ & $12.67^{\mathrm{abc}}$ & $14.33^{\mathrm{abc}}$ \\
\hline $\begin{array}{l}25 \% \text { N-urea }+75 \% \\
\text { N-PM }\end{array}$ & $19.28^{\mathrm{ab}}$ & $14.50^{\mathrm{de}}$ & $20.68^{\mathrm{b}}$ & $17.37^{\mathrm{de}}$ & $15.67^{\mathrm{ab}}$ & $9.67^{\mathrm{def}}$ \\
\hline $100 \%$ N-PM & $21.43^{\mathrm{a}}$ & $13.61^{\mathrm{f}}$ & $22.25^{\mathrm{a}}$ & $18.08^{\mathrm{cd}}$ & $16.00^{\mathrm{a}}$ & $12.33^{\mathrm{cd}}$ \\
\hline $\operatorname{SEM}( \pm)$ & \multicolumn{2}{|c|}{2.47} & \multicolumn{2}{|c|}{0.44} & \multicolumn{2}{|c|}{3.70} \\
\hline $\operatorname{LSD}_{(0.05)}$ & \multicolumn{2}{|c|}{2.16} & \multicolumn{2}{|c|}{1.12} & \multicolumn{2}{|c|}{3.30} \\
\hline $\mathrm{P}$ & \multicolumn{2}{|c|}{0.01} & \multicolumn{2}{|c|}{0.01} & \multicolumn{2}{|c|}{0.01} \\
\hline
\end{tabular}

Means within the column followed by same letter are not significant at $5 \%$ level by DMRT. DAT=Days after transplanting, SEM $( \pm)=$ Standard error of mean, LSD=least significant difference and $\mathrm{CV}=$ coefficient of variance.

It was revealed that Green Span along with poultry manure only and NAI RE KUI DA F1 with $50 \% \mathrm{~N}$-urea $+50 \% \mathrm{~N}$ - poultry manure ensured the highest records in all parameters studied. The reason behind this might be that variety being hybrid found more adoptive to inorganic fertilizer while the Green Span response was more preferable to organic source, poultry manure. Similarly when observing the interaction effect of each variety with each treatment, Green Span performed better than NAI RE KUI DA NAI RE KUI DA F1. Radovich (2000) studied the response of basil (Ocimum basilicum L.) to chicken manure, compost and urea applications and reported that response to manure applications was cultivar dependent.

\section{CONCLUSION}

Result of the study indicated that Green Span variety of lettuce performs better in Chitwan and has better adaptation capacity. Study suggests that poultry manure alone can produce better result than inorganic fertilizer alone. Besides, for sustainable and better yield of lettuce varieties, especially hybrid, integration of $50 \%$ or more poultry 
manure with urea based on precise calculation of recommended dose of nutrition is suggested.

\section{ACKNOWLEDGEMENTS}

We are very much grateful to Department of Horticulture and Directorate of Research and Extension of Agriculture and Forestry University, Chitwan for facilitating the sound study environment and National Agriculture Research and Development Fund, Nepal for the financial support.

\section{REFRENCES}

Chen, J.H. (2006). The combined use of chemical and organic fertilizers and/or biofertilizer for crop growth and soil fertility. International Workshop on Sustained Management of the soil-rhizosphere system for efficient crop production and fertilizer use, 16:20.

Dutta, S., Pal, R., Chakeraborty, A., and Chakrabarti, K. (2003). Influence of integrated plant nutrient phosphorus and sugarcane and sugar yields. Field Crop Research, 77:43 - 49.

Lairon, D., Spitz N., Termine E., Ribaud P., Lafont H., and Hauton J.C. (1984). Effect of organic and mineral nitrogen fertilization on yield and nutritive value of butter-head lettuce; Plant Foods. Hum Nutrition, 34: 97-108.

Mbatha A.L. (2008). Thesis on Influence of Organic Fertilizers on the Yield and Quality of Cabbage and Carrot; Faculty of Natural and Agricultural Sciences Department of Soil, Crop and Climate Sciences; University of the Free State; Bloemfontein. 76-94

Madisa, M.E., Mathowa, T., Mpofu, C., Stephen, N., and Machacha S. (2013). Effect of chicken manure and commercial fertilizer on performance of jute mallow (Corchorusolitorius). Agriculture And Biology Journal of North America, 4(6): 617-622.

Masarirambi, M.T., Mbokazi, B.M., Wahome, P.K., and Oseni, T.O. (2012). Effects of kraal manure, chicken manure and inorganic fertilizer on growth and yield of lettuce (Lactuca sativa L. var Commander) in a semi-arid environment. Asian Journal of Agricultural Sciences, 4(1): 58-64.

Naeem, M., Iqbal J., and Bakhsh M.A.A. (2006). Comparative study of inorganic fertilizers and organic manures on yield and yield components of mungbean (Vignaradiat L.). Journal of Agriculture and Social Sciences, 2: 227-9.

Obatolu, C.R. (1995). Nutrient balance sheet after coffee and maize cropping on an Ultisol supplied with organic fertilizer in Ibadan, Nigeria. Proceeding Green span of $3^{\text {rd }}$ African Soil Science Conference, University of Ibadan, 21-26 August, 1995.

Okokoh, S.J., and Bisong, B.W. (2011) Effect of poultry manure and urea- $\mathrm{n}$ on flowering occurrence and leaf productivity of Amranthus cruentus in Calabar. Journal of Applied Scienc and Environmental Management, 15(1): 13-15.

Radovich, T.J. (2000). The response of Basil (Ocimumbasilicum L.) to chicken manure, compost and urea applications (Doctoral dissertation, University Of Hawaii)

Richert, A.S., and Salomon, E. (1998). Application of broiler chicken manure to lettuce and cabbage crops: effect on yield, plant nutrient utilization and mineral nitrogen in the soil. Acta Horticulture, 571: 10-12. 
Sanchez, P.A and Miller, R.H. (1986). Organic matter and soil fertility management in acid soils of the tropics. Transactions of the $13{ }^{\text {th }}$ Congress of the International Soil Science Society Vol. V.

Schuphan, W. (1974). Nutritinal value of crops as influenced by organic and inorganic fertilizer treatments. Plant Foods for Human Nutrition, 23 : 333-358

Sharma, M.D. (2005). Jirisaag KoKheti. Krishi Sandesh. Post Graduate Student Society, IAAS.5-6: 4-7.

Ullah, M.S., Islam, M.S., Islam, M.A., and Haque, T. (2008). Effects of organic manures and chemical fertilizers on the yield of brinjal and soil properties. Journal of the Bangladesh Agricultural University, 6(2): 271-276.

Xu, H.L., Wang, R., Xu, R.Y., Mridha, M.A.U. and Goyal, S., (2005). Yield and quality of leafy vegetables grown with organic fertilizations. Acta Horticulture, 627: 25-33. 